\title{
SYNTHESIS OF $\beta$-DIKETIMINATE DERIVATIVES OF ZINC ALKOXIDES: CATALYTIC PROPERTIES FOR RING OPENING POLYMERIZATION
}

\author{
TAIMUR ATHAR*, ABDUL HAKEEM, NEHA TOPNANI \\ Indian Institute of Chemical Technology, Hyderabad (A.P.). India \\ (Received: March 7, 2011 - Accepted: October 13, 2011)
}

\begin{abstract}
A series of zinc (II) complexes has been prepared based on a $\beta$-diketiminate ligand framework and exhibits the highest rate of polymerization with better stereoselectivity in the formation of polylactic from the rac-lactide with aggregation and narrow polydisperties. Degree of aggregation and their reactivity's depends on the nature of alkoxy groups, the role of metal ion, solvent and their structural properties. The nature of substituent group on $\beta$-diketiminate ligand exerts a significant change affecting both the degree of selectivity and the rate of polymerization. The polymerizations are living, as evidenced by the narrow polydisperties and with their linear nature and average molecular weight.
\end{abstract}

Keywords: $\beta$-diketiminato Zinc alkoxides, PLA and PCL, Ring opening polymerization

\section{INTRODUCTION}

The remarkable advances have been reported for olefin polymerization by using single - site catalysts. The stereochemical properties of Polylactic acid (PLA) and polycaprolactone (PCL) depends on the efficiency of a catalyst. The mechanical and physical properties, as well as their chemical and biological degradation depend on the single site interaction of catalyst. Polylactic acid (PLA) and polycaprolactone (PCL) are used as biopolymer due to their biocompatibility, permeable and biodegradability properties since many years. ${ }^{1-3}$ In last one decade, many efforts have been devoted for improving ROP with the help of alkoxy based initiators. In alkoxy based catalyst the metaloxygen bonds play an important role for the ring-opening polymerizationscopolymerizations and transesterification reactions. The rate of polymerization depends on the following three parameters: nature of OR groups, the role of central metal ion and the nature of solvent in their coordinative aggregates. It is worth pointing that ROP of lactides can be initiated by alkoxy group in two-step (1) an anionic-type insertion mechanism of the monomer at the rate of propagation step without any transfer or termination reactions. Therefore the knowledge of the catalyst behaviors along with their mechanistic approach are essential at the molecular scale to better understand the conversion of monomer into poly product with better controls in molecular weight with narrow polydispersity. Ring-opening polymerization of lactides has been initiated by various metal alkoxides (Al, $\mathrm{Li}, \mathrm{Mg}, \mathrm{Fe}, \mathrm{Sn}, \mathrm{Zr} \mathrm{Zn}$ or Ti) since last one decade. ${ }_{4-10}$ So, it is important to analyze and discuss in detail the dependence of the kinetic course of the reactions with catalyst in the solution state.

Monoanionic $\beta$-diketiminate ligand have been considered to be one of the most versatile ligands in coordination chemistry and helps in fine tuning the ligand properties with functional groups which leads to the formation of strong metal -ligand bond which is capable to control stereo chemical properties via a chain -end control mechanism..$^{11-12}$

Bulky substituents on the nitrogen atoms play an important role as a catalyst for the activation of small molecule and polymerization. ${ }^{13-16}$

The formations of $\beta$-diketiminate derivatives of Zinc alkoxides such as dinuclear or trinuclear take place by changing the functional groups at the molecular level. ${ }^{15}$

The role of alkoxy group with different substituents has been investigated for their acitivity towards the formation of dinuclear and trinuclear zinc complexes.

Herein we report the synthesis, structure of $\beta$-diketiminate $\mathrm{Zn}$ alkoxide complexes along with their solid-state molecular structures, their dynamic behavior and their reactivity towards ROP based on b-diketiminate ligand by using the concepts of molecular recognition within architectural properties of macromolecules.

\section{EXPERIMENTAL PART}

General Procedure

The reaction was performed in an inert atmosphere by using Schlenk line. Solvents were distilled under nitrogen prior to use. Starting materials were purchased from Aldrich and used as such. Ligands were synthesized as reported in the literature. ${ }^{14}$

Rac -Lactide was sublimed under vacuum at $50^{\circ} \mathrm{C} .{ }^{1} \mathrm{H}$ and ${ }^{13} \mathrm{C}$ NMR spectra were recorded on a Varian Unity Inova-600 ( $600 \mathrm{MHz}$ for ${ }^{1} \mathrm{H}$ and $150 \mathrm{MHz}$ for ${ }^{13} \mathrm{C}$ ) or a Varian Mercury-400 ( $400 \mathrm{MHz}$ for ${ }^{1} \mathrm{H}$ and $100 \mathrm{MHz}$ for ${ }^{13} \mathrm{C}$ ) spectrometer by using TMS as an internal standard for $\left({ }^{1} \mathrm{H}\right)$ or the central line of $\mathrm{CDCl}_{3}\left({ }^{13} \mathrm{C}\right)$. Microanalyses were performed by using a Heraeus -RAPID instrument Results within $\pm 0.4 \%$ with the theoretical value. GPC measurements were performed on Postnova PN1122 by using THF as solvent delivery system with TriSEC GPC software at $35^{\circ} \mathrm{C}$. Molecular weight and polydispersity indexes were calculated by using polystyrene as a standard.

Ligand Synthesis: The ligands with same $\mathrm{N}$-aryl substituents in $\beta$-diketiminate was prepared by using 2.0 equiv of $\mathrm{ArNH}_{2}$ in 2, 4-pentanedione in toluene by using p-toluenesulfonic acid as catalyst and then refluxed for 2 days. The ligands with different $\mathrm{N}$-aryl substituents in $\beta$-diketiminate was prepared by using 1.0 equiv of $\mathrm{ArNH}_{2}$ with 2,4-pentanedione in toluene with p-toluenesulfonic acid as catalyst and then refluxed for 1day by using the same equivalent aniline $\left(\mathrm{Ar}^{\prime} \mathrm{NH}_{2}\right)$ was added into the solution and refluxed again for 2 days

Synthesis of $\left[\{(\text { BDI-2 }) \mathrm{Zn}(\mathrm{m}-\mathrm{OBn})\}_{2} \mathrm{Zn}(\mathrm{m}-\mathrm{OBn})_{2}\right]$

The synthesis of 2-( 2-Methoxyphenylimino )-4-( 2 , 6-diisopropylphenylamido )-pent-2-ene ( BDI-2 ) and [( BDI-2 )ZnEt] was carried out as reported by Gibson ${ }^{[14]}$ ( BDI-2 ) ZnEt ( 2 g , $4.37 \mathrm{mmol}$ ) was dissolved in $20 \mathrm{ml}$ hexane, followed by dropwise of addition of benzyl alcohol ( $0.55 \mathrm{~mL}, 5.24 \mathrm{mmol}$ ) at $0^{\circ} \mathrm{C}$ with continuous stirring for 30 minutes . The solution was warmed to room temperature and then stirred for 12 hours till white solids precipitated out. The mixture was filtered through celite .The filtrate was concentrated and white solid was crystallized from dried toluene solids at $0^{\circ} \mathrm{C}$. Yield: $2.2 \mathrm{~g}(1.62 \mathrm{mmol}, 37 \%) .{ }^{1} \mathrm{H} \mathrm{NMR}\left(\mathrm{CDCl}_{3}, \mathrm{ppm}\right)$ at room temperature: $\delta 7.10-6.45(17 \mathrm{H}, \mathrm{m}, \mathrm{Ar} \boldsymbol{H}), 4.69\left(1 \mathrm{H}, \mathrm{s}, 1 \mathrm{H}, \mathrm{s}, \boldsymbol{H C}\{\mathrm{C}(\mathrm{Me}) \mathrm{NAr}\}_{2}\right.$ ), 4.14 ( 4H, br s, $\mathrm{OCH}_{2} \mathrm{Ar}$ ), 3.44 ( 3H, s, OCH $\left.\boldsymbol{H}_{3}\right), 2.87$ ( $2 \mathrm{H}$, br s, $\mathrm{CH} \mathrm{Me}_{2}$ ), $1.64\left(3 \mathrm{H}, \mathrm{s}, \mathrm{HC}\left\{\left(\mathrm{CH}_{3}\right) \mathrm{C}=\mathrm{N}\left({ }^{o-\mathrm{Me}} \mathrm{Ar}\right)\right\}, 1.56\left(3 \mathrm{H}, \mathrm{s},\left(\mathrm{CH}_{3}\right) \mathrm{C}=\mathrm{N}\left({ }^{2,6-\mathrm{Dilpr}} \mathrm{Ar}\right)\right), 0.94\right.$ $\left(6 \mathrm{H}, \mathrm{d}, J_{\mathrm{H}-\mathrm{H}}=6.8 \mathrm{~Hz}, \operatorname{ArCH}\left(\mathrm{CH}_{3}\right)_{2}\right), 0.77\left(6 \mathrm{H}, \mathrm{s}, \operatorname{ArCH}\left(\mathrm{CH}_{3}\right)_{2}\right) \cdot{ }^{13} \mathrm{C} \mathrm{NMR}$ $\left(\mathrm{CDCl}_{3}, \mathrm{ppm}\right)$ at room temperature: $\delta 168.10\left(\mathrm{HC}\left\{\boldsymbol{C}\left(\mathrm{CH}_{3}\right) \mathrm{NAAr}\right\}\right), 167.92$ $\left(\mathrm{HC}\left\{\boldsymbol{C}\left(\mathrm{CH}_{3}\right) \mathrm{NAr}\right\}\right), 152.63(\mathrm{MeOCCN}), 144.41\left(\mathrm{NCCCMe}_{2}\right), 142.46($ $\mathrm{NCCCMe}_{2}$ ), 138.77 ( $\mathrm{MeOCCN}$ ), 127.74, 127.02, 125.73, 124.86, 124.64, $123.35,120.74,111.70(\boldsymbol{P h}), 94.51\left(\mathrm{H} \boldsymbol{C}\left\{\mathrm{C}\left(\mathrm{CH}_{3}\right) \mathrm{NAr}_{2}\right), 68.30\left(\mathrm{Ph}_{\boldsymbol{C}} \mathrm{O} \mathrm{O}\right)\right.$, $55.207\left(\boldsymbol{C H}_{3} \mathrm{O}\right), 27.45\left(\mathrm{ArCH}\left(\mathrm{CH}_{3}\right)_{2}\right), 24.14\left(\operatorname{ArCH}\left(\boldsymbol{C H}_{3}\right)_{2}\right),\left(\operatorname{ArCH}\left(\boldsymbol{C H}_{3}\right)_{2}\right.$ )$, 23.71\left(\mathrm{HC}\left\{\mathrm{C}\left(\boldsymbol{C H}_{3}\right) \mathrm{NAr}\right\}_{2}\right), 22.89\left(\mathrm{HC}\left\{\mathrm{C}\left(\boldsymbol{C H}_{3}\right) \mathrm{NAr}\right\}_{2}\right)$. Elemental analysis calc. for $\mathrm{C}_{76} \mathrm{H}_{90} \mathrm{~N}_{4} \mathrm{O}_{6} \mathrm{Zn}_{3} \cdot \mathrm{C}_{6} \mathrm{H}_{5} \mathrm{CH}_{3}: \mathrm{C}: 69.04, \mathrm{H}: 6.84, \mathrm{~N}: 3.88 \%$, Found: C: 68.82, H: $6.71, \mathrm{~N}: 3.81 \%$.

Synthesis of 2-(2-methoxyphenylimino)-4-(pentafluorophenylamido)2-pentene. $\left(\mathbf{L}_{1}-\mathbf{H}\right)$. A toluene solution of pentafluoroaniline $(21 \mathrm{~g}, 110 \mathrm{mmol})$ with catalytic amount $(0.1 \mathrm{~g})$ of $p$-toluenesulfonic acid was added with 2, 4 -pentanedione $(12 \mathrm{~mL}, 120 \mathrm{mmol})$. After being refluxed for $24 \mathrm{~h}$ with water being continuously removed by using a Dean-Stark trap. Volatile materials were removed under vacuum the resulting to the formation of slurry .Slurry was 
suspended in toluene $(100 \mathrm{ml})$ followed by an addition of 2-methoxyaniline $(14 \mathrm{~mL}, 120 \mathrm{mmol})$. The solution was refluxed for $48 \mathrm{~h}$ with water being removed by using a Dean-Stark trap again. The product was purified by column chromatography. The filtrate was dried in vacuum to gives a yellow solid. Yield: $29 \mathrm{~g}(71 \%) .{ }^{1} \mathrm{H}$ NMR $\left(\mathrm{CDCl}_{3}, 400 \mathrm{MHz}\right)$ at room temperature: $d 12.38(1 \mathrm{H}$, $\mathrm{s}, \mathrm{NH}), 7.15-6.89(4 \mathrm{H}, \mathrm{m}, \mathrm{ArH}), 5.00(1 \mathrm{H}, \mathrm{s}, b-\mathrm{CH}), 3.81\left(3 \mathrm{H}, \mathrm{s}, \mathrm{ArOCH}_{3}\right)$ $2.12\left(3 \mathrm{H}, \mathrm{s}, \mathrm{CH}_{3} \mathrm{CNArF}_{5}\right), 1.93\left(3 \mathrm{H}, \mathrm{s}, \mathrm{CH}_{3} \mathrm{CNArOMe}\right) .{ }^{13} \mathrm{C} \mathrm{NMR}\left(\mathrm{CDCl}_{3}, 400\right.$ $\mathrm{MHz})$ : at room temperature $d 171.45\left(\mathrm{CH}_{3} \mathrm{CNArF}_{5}\right), 155.87\left(\mathrm{CH}_{3} \mathbf{C N H O M e}\right)$, $152.31(\mathrm{MeOCCN}), 140.53,139.09,138.92,137.55,136.74,136.46,128.95$, $126.08,125.36,124.19,120.28,111.22(\mathrm{Ph}), 97.54(b-\mathrm{C}), 55.64\left(\mathrm{OCH}_{3}\right), 22.23$ $\left(\mathbf{C H}_{3} \mathrm{CNArOMe}\right), 20.60\left(\mathbf{C H}_{3} \mathrm{CNHF}_{5}\right)$. Anal. Calc. (Found) for $\mathrm{C}_{18} \mathrm{H}_{15} \mathrm{~F}_{5} \mathrm{~N}_{2} \mathrm{O}: \mathrm{C}$ 58.38 (58.73), H 4.08 (4.12), N 7.56 (7.57) \%.

Synthesis of $\left[\left(\mathbf{L}_{1}\right)_{2} \mathbf{Z n}_{2}(\mu-\mathbf{O B n})_{2}\right]$. A $\mathrm{L}_{1}-\mathrm{H}(0.37 \mathrm{~g}, 1.00 \mathrm{mmol})$ was taken in hexane followed by the addition of diethyl zinc $(1.2 \mathrm{~mL}, 1.2 \mathrm{mmol})$. After being stirred at $0^{\circ} \mathrm{C}$ for $8 \mathrm{hrs}$, a light yellow solution was obtained. Volatile materials were removed in vacuum to yield yellow oil. Oil was taken in hexane $(20 \mathrm{~mL})$ followed by the addition of $\mathrm{BnOH}(0.11 \mathrm{~mL}, 1.0 \mathrm{mmol})$, the mixture was stirred for 8 hrs. Volatile materials were removed to yield a light yellow powder. The solid was recrystallized from toluene at $0^{\circ} \mathrm{C}$ to yield colorless crystals. Yield: $0.34 \mathrm{~g} \mathrm{(31 \% ).}{ }^{1} \mathrm{H} \mathrm{NMR}\left(\mathrm{CDCl}_{3}, 400 \mathrm{MHz}\right)$ at room temperature: $d$ 7.28-6.51 (9H, m, ArH), $4.75(1 \mathrm{H}, \mathrm{s}, b-\mathrm{CH}), 4.57\left(2 \mathrm{H}, \mathrm{br} \mathrm{s}, \mathrm{PhCH}_{2} \mathrm{O}\right), 3.61$ $\left(3 \mathrm{H}, \mathrm{s}, \mathrm{ArOCH}_{3}\right), 1.61\left(3 \mathrm{H}, \mathrm{s}, \mathrm{CH}_{3} \mathrm{CNArF}_{5}\right), 1.38\left(3 \mathrm{H}, \mathrm{s}, \mathrm{CH}_{3} \mathrm{CNArOMe}\right) .{ }^{13} \mathrm{C}$ NMR $\left(\mathrm{CDCl}_{3}, 400 \mathrm{MHz}\right)$ at room temperature: $d 171.93\left(\mathrm{CH}_{3} \mathrm{CNArF}_{5}\right), 166.72$ ( $\mathrm{CH}_{3}$ CNHOMe), $152.02(\mathrm{MeOCCN}), 145.00,143.29,140.78,139.09,138.50$, $137.56,136.65,136.03,129.02,128.21,127.91,125.45,125.29,119.65(\mathrm{Ph})$ $95.90(b-\mathrm{C}), 68.85\left(\mathrm{PhCH}_{2} \mathrm{O}\right), 55.03\left(\mathrm{OCH}_{3}\right), 23.16\left(\mathbf{C H}_{3} \mathrm{CNArOMe}\right), 20.56$ $\left(\mathrm{CH}_{3} \mathrm{CNHF}_{5}\right)$. Anal. Calc. (Found) for $\mathrm{C}_{52} \mathrm{H}_{48} \mathrm{~F}_{10} \mathrm{~N}_{4} \mathrm{O}_{4} \mathrm{Zn}_{2}\left[\left(\mathrm{~L}_{6}\right)_{2} \mathrm{Zn}_{2}(\mu-\mathrm{OBn})_{2}\right.$. $\mathrm{C}_{2} \mathrm{H}_{6}$ ]: C 56.08 (56.76), H 4.34 (4.98), N $5.03(5.48) \%$.

Synthesis of $2-(2,6$ - diisopropylphenylimino $)-4-(4-$ chlorophenylimino ) - pent - 2 - ene ( BDI-DiiPr- ${ }^{p} \mathrm{Cl}-\mathrm{H}$ ).

2, 6-Diisopropylaniline $(5.5 \mathrm{~g}, 31 \mathrm{mmole})$ was taken in toluene in the presence of catalytic amount of para-toluenesulfonic acid, the 2, 4-pentadione (3.1 $\mathrm{mL}, 30 \mathrm{mmol}$ ) was added. The mixture was refluxed for $36 \mathrm{hrs}$ by using Dean-Stark trap.

Volatile materials were removed in vacuum followed by the addition of 4-chloroaniline (3.95 g , $30.8 \mathrm{mmol}$ ) in $20 \mathrm{ml}$ toluene and then refluxed for $36 \mathrm{hrs}$ to remove of water completely by using a Dean-Stark trap. A clear solution was dried in vacuo after extracting with toluene to yield black solid. Recrystallization of the complex takes place in 24 hours at $-18^{\circ} \mathrm{C}$ in ethanol to yield light yellow crystals. Yield: $8.52 \mathrm{~g}(23 \mathrm{mmol}, 75 \%)$. ${ }^{1} \mathrm{H} \mathrm{NMR}\left(\mathrm{CDCl}_{3}\right.$ , ppm ) at room temperature: $\delta 12.55(1 \mathrm{H}, \mathrm{s}, \mathrm{NH}), 7.23-7.14(5 \mathrm{H}, \mathrm{m}, \mathrm{ArH}$ ), $6.82(2 \mathrm{H}, \mathrm{d}, \mathrm{ArH}), 4.88(1 \mathrm{H}, \mathrm{s}, \mathbf{H C}\{\mathrm{C}(\mathrm{Me}) \mathrm{NAr}\}), 3.00(2 \mathrm{H}, \mathrm{sept}, \mathrm{J}$ $\left.=6 \mathrm{~Hz}, \mathrm{CH}(\mathrm{Me})_{2}\right), 2.01\left(3 \mathrm{H}, \mathrm{s}, \mathrm{H}_{3} \mathrm{CC}=\mathrm{N}\left({ }^{0-\mathrm{Cl}} \mathrm{Ar}\right)\right), 1.56\left(3 \mathrm{H}, \mathrm{s}, \mathrm{H}_{3} \mathrm{CC}=\mathrm{N}^{2}{ }^{2,6-6}\right.$ $\left.{ }^{\text {Dilpr } A r) ~}\right), 1.21\left(6 \mathrm{H}, \mathrm{d}, \mathrm{J}=6.8 \mathrm{~Hz}, \operatorname{ArCH}\left(\mathrm{CH}_{3}\right)\right), 1.12\left(6 \mathrm{H}, \mathrm{d}, \mathrm{J}_{\mathrm{H}}=6.6\right.$ $\left.\mathrm{Hz}, \mathrm{ArCH}\left(\mathrm{CH}_{3}\right)_{2}\right) \cdot{ }^{13} \mathrm{C} \mathrm{NMR}\left(\mathrm{CDCl}_{3}, \mathrm{ppm}\right)$ at room temperature $: \delta 161.39$ $\left(\mathrm{HC}\left\{\boldsymbol{C}\left(\mathrm{CH}_{3}\right) \mathrm{NAr}\right\}\right), 159.31\left(\mathrm{HC}\left\{\boldsymbol{C}\left(\mathrm{CH}_{3}\right) \mathrm{NAr}\right\}\right), 144.80,142.20,140.44$, $128.75,127.88,125.31,123.40,123.03$ ( Ph $), 95.82\left(\mathrm{HC}\left\{\mathrm{C}\left(\mathrm{CH}_{3}\right) \mathrm{NAr}\right\}_{2}\right)$, $28.31\left(\mathrm{Ar} \boldsymbol{C H}\left(\mathrm{CH}_{3}\right)_{2}\right), 24.28\left(\mathrm{ArCH}\left(\mathrm{CH}_{3}\right)_{2}\right), 22.55\left(\mathrm{ArCH}\left(\boldsymbol{C H}_{3}\right)_{2}\right), 20.77$ $\left.\left(\mathrm{H}_{3} \boldsymbol{C C}=\mathrm{N}{ }^{o-C l} \mathrm{Ar}\right)\right), 20.66\left(\mathrm{H}_{3} \boldsymbol{C C}=\mathrm{N}\left({ }^{2,6-\text {-Dilpr }} \mathrm{Ar}\right)\right.$. Mass spectrum $(\mathrm{EI}, \mathrm{m} / \mathrm{e})$ : $368.4[\mathrm{M}]^{+}$. Elemental analysis calc. for $\mathrm{C}_{23} \mathrm{H}_{29} \mathrm{ClN}_{2}$ : C: $74.88, \mathrm{H}: 7.92, \mathrm{~N}$ : 7.59\%, Found: C: $74.50, \mathrm{H}: 7.68, \mathrm{~N}: 7.24 \%$.

Synthesis of $\left[\left(\text { BDI-DiiPr- }{ }^{p} \mathbf{C l}\right) \mathbf{Z n}\left(\mathbf{m}-\mathrm{O}^{i} \mathrm{Pr}\right)\right]_{2}$

(BDI-DiiPr $\left.{ }^{p} \mathrm{Cl}-\mathrm{H}\right)(5 \mathrm{~g}, 13.5 \mathrm{mmol})$ was dissolved in hexane, $\mathrm{ZnEt}_{2}(1 \mathrm{M}$ in hexane, $16 \mathrm{ml}, 16 \mathrm{mmol}$ ) was added drop wise at $0^{\circ} \mathrm{C}$. The reaction mixture was stirred for 12 hours at ambient temperature.

A volatile material was removed by vacuum followed by recrystallization to takes place within 12 hours at $0^{\circ} \mathrm{C}$ in ethanol to yield white crystal. Yield: $3.52 \mathrm{~g}(3.575 \mathrm{mmole}, 65 \%) .{ }^{1} \mathrm{H}$ NMR $\left(\mathrm{CDCl}_{3}, \mathrm{ppm}\right)$ at room temperature: $\delta$ 7.27-7.16 (3H, m, ArH ), 6.62( 2H, d, ArH $), 6.46(2 \mathrm{H}, \mathrm{t}, \operatorname{Ar} \boldsymbol{H}), 4.81(1 \mathrm{H}$ s, $\left.\boldsymbol{H C}\{\mathrm{C}(\mathrm{Me}) \mathrm{NAr}\}), 3.73(1 \mathrm{H} \text {, sept, } \mathrm{OCH}(\mathrm{Me}))_{2}\right), 3.18(2 \mathrm{H}$, sept, $\mathrm{CH}(\mathrm{Me})$ ), $1.80\left(3 \mathrm{H}, \mathrm{s}, \mathrm{HC}\left\{\mathrm{C}\left(\mathrm{CH}_{3}\right) \mathrm{NAr}\right\}_{2}\right), 1.58\left(3 \mathrm{H}, \mathrm{s}, \mathrm{HC}\left\{\mathrm{C}\left(\mathrm{CH}_{3}\right) \mathrm{NAr}\right\}_{2}\right), 1.11$ $\left.6 \mathrm{H}, \mathrm{d}, J_{\mathrm{H}}=6.4 \mathrm{~Hz}, \operatorname{ArCH}\left(\mathrm{CH}_{3}\right)_{2}\right), 1.07\left(6 \mathrm{H}, \mathrm{d}, J_{\mathrm{H}}=7.2 \mathrm{~Hz}, \operatorname{ArCH}\left(\mathrm{CH}_{3}\right)_{2}\right)$, $\left.0.74\left(3 \mathrm{H}, \mathrm{d}, J_{\mathrm{H}-\mathrm{H}}=7 \mathrm{~Hz}, \mathrm{OCH}\left(\mathrm{CH}_{3}\right)_{2}\right), 0.66\left(3 \mathrm{H}, \mathrm{d}, J_{\mathrm{H}-\mathrm{H}}=7 \mathrm{~Hz}, \mathrm{OCH}(\mathbf{C H})_{2}\right)\right)$. ${ }^{13} \mathrm{C} \mathrm{NMR}$ ( $\mathrm{CDCl}_{3}, \mathrm{ppm}$ ) at room temperature: $\delta 169.47\left(\mathrm{HC}\left\{\boldsymbol{C}\left(\mathrm{CH}_{3}\right) \mathrm{NAr}\right\}\right)$, $165.82\left(\mathrm{HC}\left\{\boldsymbol{C}\left(\mathrm{CH}_{3}\right) \mathrm{NAr}\right\}\right), 148.14,146.09,142.47,128.23,127.90,126.39$, 125.64, 123.90 ( Ph $\left.\left.), 96.69\left(\mathrm{HC}\left\{\mathrm{C}_{(\mathrm{CH}}\right) \mathrm{NAr}\right\}\right\}_{2}\right), 65.59\left(\mathrm{OCHMe}_{2}\right), 27.76$ ( $\left.\operatorname{Ar} \boldsymbol{C H}\left(\mathrm{CH}_{3}\right)_{2}\right), 27.37\left(\mathrm{OC}\left(\mathrm{CH}_{3}\right)_{2}\right), 27.02\left(\mathrm{OC}\left(\boldsymbol{C H}_{3}\right)_{2}\right), 24.62\left(\operatorname{ArCH}\left(\boldsymbol{C H}_{3}\right)_{2}\right)$, $24.47\left(\mathrm{ArCH}\left(\boldsymbol{C H}_{3}\right)_{2}\right), 24.37\left(\mathrm{HC}\left\{\mathrm{C}\left(\boldsymbol{C H}_{3}\right) \mathrm{NAr}\right\}_{2}\right), 23.82\left(\mathrm{HC}\left\{\mathrm{C}\left(\boldsymbol{C} \mathrm{C}_{3}\right) \mathrm{NAr}_{2}\right)\right.$. Elemental analysis calc. for $\mathrm{C}_{6} \mathrm{H}_{2} \mathrm{Cl}_{2} \mathrm{~N}_{2} \mathrm{Zn}_{2}: \mathrm{C}: 63.19, \mathrm{H}: 6.74, \mathrm{~N}: 5.76 \%$, Found:C: $63.42, \mathrm{H}: 7.16, \mathrm{~N}: 5.69 \%$.

Polymerization procedure: A typical polymerization procedure was carried out by the synthesis of PLA at room temperature with the conversion yield $(94 \%)$ as supported by ${ }^{1} \mathrm{H}$ NMR spectroscopic studies. A mixture of catalyst $(0.0506 \mathrm{~g}, 0.05 \mathrm{mmol})$ and L-lactide $(0.72 \mathrm{~g}, 20 \mathrm{mmol})$ in toluene $(20 \mathrm{~mL})$ was stirred at room temperature for $2 \mathrm{~min}$. Volatile materials were removed and the residue was redissove in THF $(10 \mathrm{~mL})$. The mixture was quenched with an aqueous acetic acid solution $(0.35 \mathrm{~N}, 10 \mathrm{~mL})$ and the polymer was precipitated out in $n$-hexane $(40 \mathrm{~mL})$ to give white crystalline solids. Yield: $0.52 \mathrm{~g}(72 \%)$

\section{RESULTS AND DISCUSSION}

Effect of functional group in $\mathrm{N}$-aryl positions on the structure of $\beta$-diketiminate $\mathrm{Zn}$ complexes:

The utility of above synthetic methodology for the preparation of zinc complexes with a dinuclear and trinuclear complexes takes place with the help of alkoxy ligands has been investigated. These complexes have wide range potential applications. These studies show the effect of $\beta$-diketiminate $\mathrm{Zn}$ alkoxide complexes with the help polar interactions. All dinuclear complexes obtained by substitution with an electron donating groups at the $\mathrm{N}$-aryl positions. However the trinuclear complexes were obtained with the help of electron withdrawing groups at the 1 or 3 positions in pentene along with iso-propyl group at the 2,6 N -aryl positions. With the presence of an electronegative substitution the polar interaction helps to overcomes the p-resonance effect leads to formation of trinuclear complex with the help of s-electron withdrawing effect. Spectroscopic and elemental analysis data are consistent with the representative compound. The mechanism for the formation of these complexes is shown in equation 1.

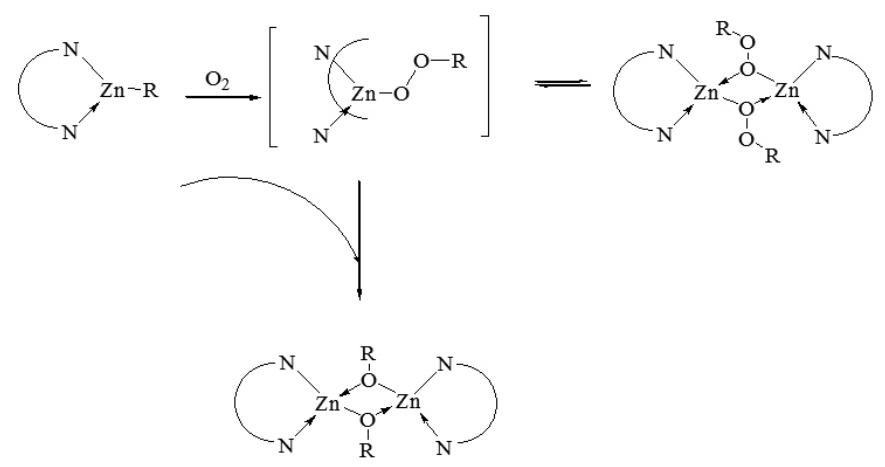

equation 1.

Ring Opening Polymerization of Lactides Initiated by $\beta$-diketiminate Zn complex:

Alkoxides are considered as a potential precursor as a single-site catalyst due to their high electropositive nature of elements which are stabilized by the electronegative oxygen atoms, which will leads to a decrease in the reactivity towards a acid-base side interaction which will leads to an anionic polymerization in lactones. The slow activity in the alkoxide-bridged dimer with different initiating groups leads to the difference in the catalytic action.

A preliminary experiment was conducted to investigate the utility of the $\beta$-diketiminate ligands as a catalysts towards polymerization of rac-lactide by using different functional groups at $\mathrm{N}$-aryl position. These catalysts show the good ROP to yield PLA with narrow polydispersties and good molecular weight control and stereoselectivity. With the help of electrons donating group at the $\mathrm{N}$-aryl positions the polymerization reactions takes less than 10 mins. The rate of polymerization differs with functional groups depending in the position at the $\mathrm{N}$-aryl substitution. It is concluded that Lewis acidity character increases at the Zinc center due to the presence of an electron withdrawing groups and lead to the formation of strong bond between $\mathrm{Zinc}$ and $\mathrm{BnO}^{-}$thereby affecting the rate of ROP.

Ring opening polymerization (ROP) of L-lactide (LLA) with complexes $1-3$ was systematically examined in an inert atmosphere. These experimental results show the complex $1 \mathrm{act}$ as an efficient initiator for the polymerization of LLA. More than $90 \%$ conversion takes place within $3 \mathrm{~min}$ in toluene at ambient temperature and with narrow PDIs (1.09-1.18) as illustrated in Table $1 .{ }^{15} \mathrm{All}$ four $\mathrm{BnO}^{-}$groups could be used as initiators on trinuclear $\mathrm{Zn}$ complex. The $\mathrm{Mn}$ versus $[\text { LLA }]_{0} /[1]$ ratio plot as shown in Figure1. 
Table 1 Polymerization of L-lactide using complex 1 as an initiator.

\begin{tabular}{|c|c|c|c|c|c|c|c|}
\hline Entry & {$[\mathrm{M}] /[\mathrm{Zn}]$} & Temp. & Time $(\min )$ & $\mathrm{Mn}(\mathrm{GPC})^{\mathrm{a}}$ & $\mathrm{Mn}(\mathrm{cal} .)^{\mathrm{b}}$ & Conv.(\%) $^{\mathrm{c}}$ & PDI \\
\hline 1 & 40 & r.t & 3 & 3299 & 1600 & $>99$ & 1.15 \\
\hline 2 & 60 & r.t & 3 & 5100 & 2300 & $>99$ & 1.18 \\
\hline 3 & 80 & r.t & 3 & 8000 & 3000 & $>99$ & 1.10 \\
\hline 4 & 100 & r.t. & 3 & 10483 & 3700 & $>99$ & 1.09 \\
\hline
\end{tabular}

a Obtained from GPC analysis and calibrated by polystyrene standard. ${ }^{b}$ Calculated from the molecular weight of L-lactide $\mathrm{x}[\mathrm{M}]_{0} / 4[1]_{0} \mathrm{x}$ conversion yield plus $\mathrm{Mw}(\mathrm{BnOH}) .{ }^{c} \mathrm{Obtained}$ from ${ }^{1} \mathrm{H}$ NMR analysis.

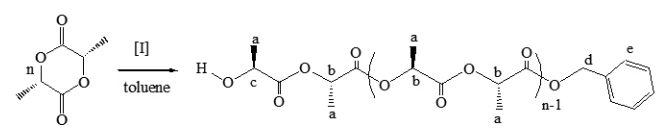

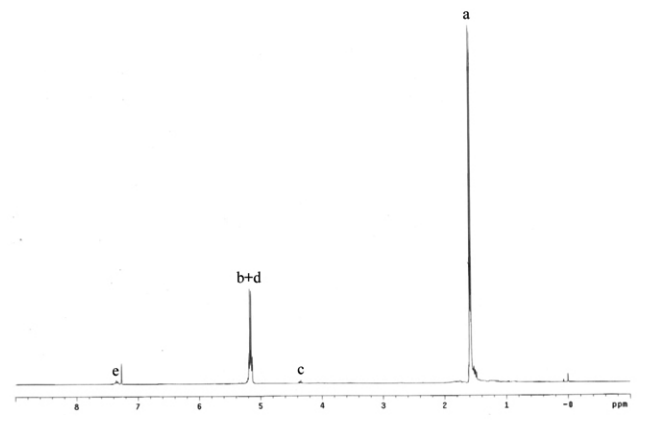

${ }^{1} \mathrm{H}$ NMR spectrum of PLA-50 catalyzed by compound 3 at $50^{\circ} \mathrm{C}$

Figure 1. Synthesis of polylactide ${ }^{1} \mathrm{H}$ NMR spectrum of PLA-50 catalyzed by compound $\mathbf{3}$ at $50^{\circ} \mathrm{C}$

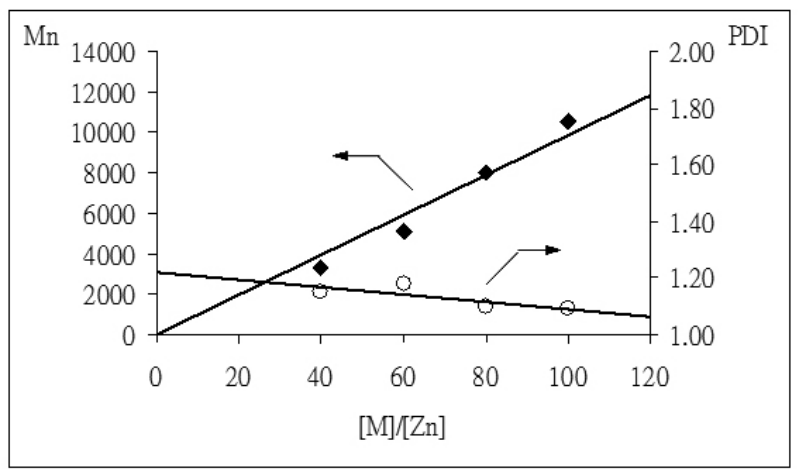

Figure 2. Plot of $\mathrm{Mn}(\mathrm{GPC})$ vs. $[\mathrm{M}] /[\mathrm{Zn}]$ with polydispersity indices indicated by closed circles (GPC).

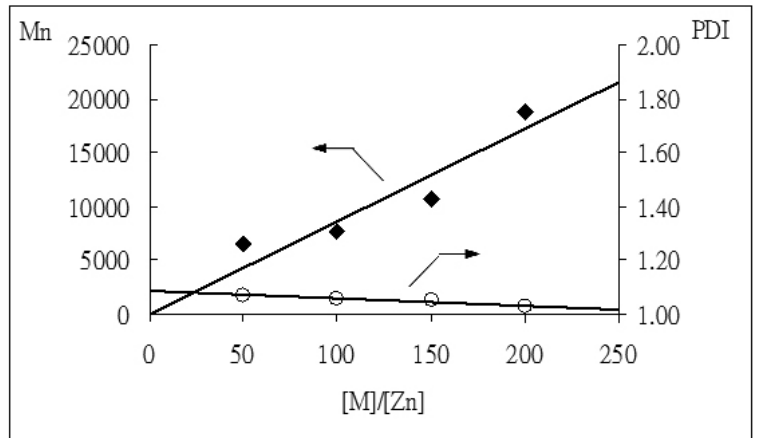

Figure 3. Plot of $M \mathrm{n}(\mathrm{GPC})$ vs. $[\mathrm{M}] /[\mathrm{Zn}]$ with polydispersity indices indicated by closed circles (GPC).

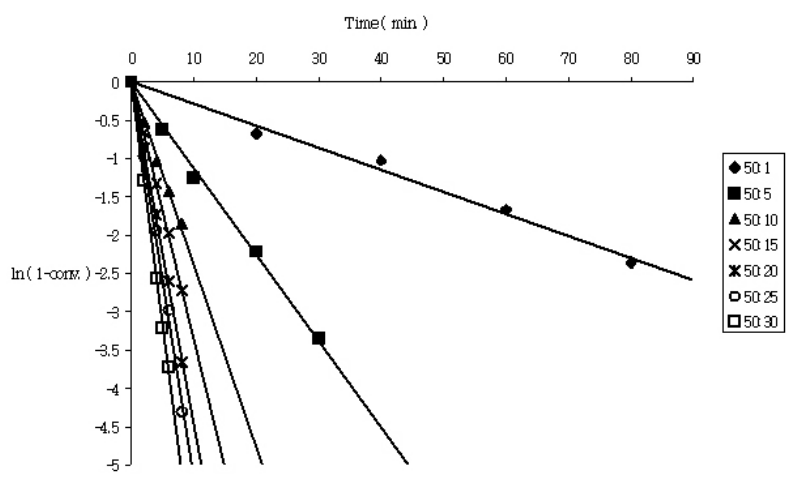

Figure 4. First-order kinetic plots for L-lactide polymerizations with time in toluene with different concentration of complex $\mathbf{4}$ as an initiator.

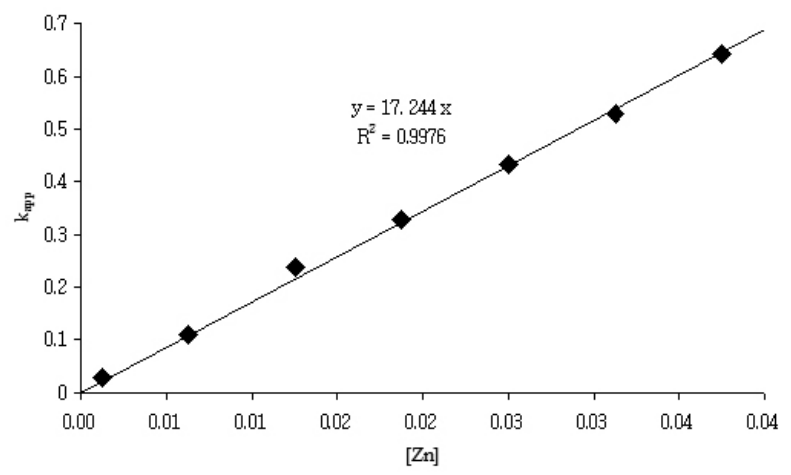

Figure 5. Linear plot of $\mathrm{k}_{\mathrm{obs}}$ versus $[\mathbf{1}]$ for the polymerization of L-lactide with $[\mathrm{LA}]_{0}=0.5 \mathrm{M}$ in toluene. $k=17.24 \mathrm{M}^{-2} \mathrm{~s}^{-1}$

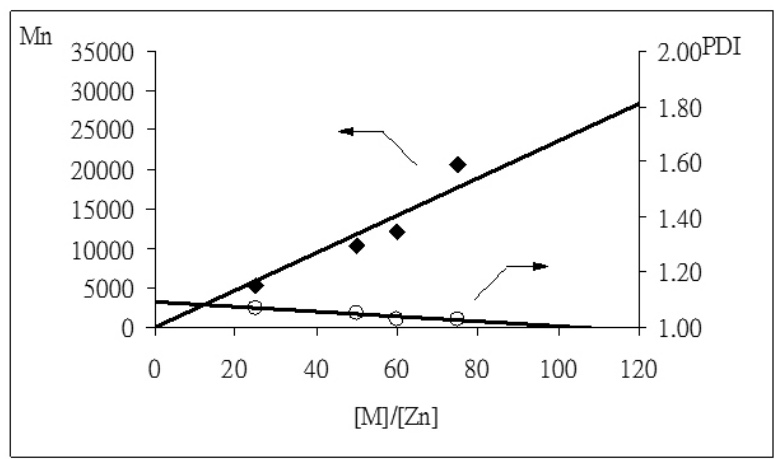

Figure 6. Plot of $\mathrm{Mn}(\mathrm{GPC})$ vs. $[\mathrm{M}] /[\mathrm{Zn}]$ with polydispersity indices indicated by closed circles (GPC). 
Table 2 Polymerization of L-lactide using complex 2 as an initiator.

\begin{tabular}{|c|c|c|c|c|c|c|c|}
\hline Entry & {$[\mathrm{M}] /[\mathrm{Zn}]$} & Temp. & Time $(\mathrm{h})$ & $\mathrm{Mn}(\mathrm{GPC})^{\mathrm{a}}$ & $\left.\mathrm{Mn}^{\mathrm{c}} \mathrm{cal}.\right)^{\mathrm{b}}$ & Conv.(\%) $^{\mathrm{c}}$ & PDI \\
\hline 1 & 50 & r.t. & 2 & 6500 & 3700 & $>99$ & 1.07 \\
\hline 2 & 100 & r.t. & 2 & 7700 & 7300 & $>99$ & 1.06 \\
\hline 3 & 150 & r.t. & 2 & 10700 & 10900 & $>99$ & 1.05 \\
\hline 4 & 200 & r.t. & 2 & 18800 & 14500 & $>99$ & 1.03 \\
\hline
\end{tabular}

${ }^{a}$ Obtained from GPC analysis and calibrated by polystyrene standard. ${ }^{b}$ Calculated from the molecular weight of L-lactide $\mathrm{x}[\mathrm{M}]_{0} / 4[1]_{0} \mathrm{x}$ conversion yield plus $\mathrm{Mw}(\mathrm{BnOH}) .{ }^{c}$ Obtained from ${ }^{1} \mathrm{H}$ NMR analysis.

Table 3 Polymerization of L-lactide using complex 3 as an initiator.

\begin{tabular}{|c|c|c|c|c|c|c|c|}
\hline Entry & {$[\mathrm{M}] /[\mathrm{Zn}]$} & Temp. & Time $(\min )$ & $\mathrm{Mn}(\mathrm{GPC})^{\mathrm{a}}$ & $\mathrm{Mn}^{\mathrm{ccal} .)^{\mathrm{b}}}$ & Conv.(\%) $^{\mathbf{c}}$ & PDI \\
\hline 1 & 25 & r.t & 20 & 5200 & 3650 & $>99$ & 1.07 \\
\hline 2 & 50 & r.t & 20 & 10300 & 7250 & $>99$ & 1.05 \\
\hline 3 & 60 & r.t & 20 & 12050 & 8300 & 96 & 1.03 \\
\hline 4 & 75 & r.t & 20 & 20700 & 10850 & $>99$ & 1.03 \\
\hline
\end{tabular}

${ }^{a}$ Obtained from GPC analysis and calibrated by polystyrene standard. ${ }^{b}$ Calculated

from the molecular weight of L-lactide $\mathrm{x}[\mathrm{M}]_{0} / 4[1]_{0}$ x conversion yield plus $\mathrm{Mw}(\mathrm{BnOH}) .{ }^{c}$ Obtained from ${ }^{1} \mathrm{H}$ NMR analysis.

The ROP reaction was carried out with complex 2; the results are given in Table 2. When the [LLA $]_{0} /[2]$ ratio was increased, $M n$ of PLLA was increased linearly, supporting the living property of polymerization with complex 2 . PDI (1.03-1.07) as illustrated in table 2 .The $M n$ versus [LLA $]_{0} /[2]$ ratio plot shown as Figure 4. Electron withdrawing group attack the carbonyl group of lactide by increasing Lewis acidic character of alkoxy group. More than $90 \%$ conversion takes place within $2 \mathrm{hrs}$ at room temperature in toluene, and their kinetic studies ${ }^{13-14}$ reveals the catalytic process follows the first order reaction and with a kinetic constant $k=17.24 \mathrm{M}^{-2} \mathrm{~s}^{-1}$ which are independent of type of monomer used along its and complex concentration.( Figure 3 and 4). More than $90 \%$ conversion takes place within $20 \mathrm{~min}$ at room with complex 3 at a desired [LLA $]_{0} /[3]$ ratio in toluene and with PDIs in the range of (1.09-1.18) as shown in Table 3. These results support the living property before the reaction was quenched. The $M n$ versus [LLA $]_{0} /[3]$ ratio plot was shown as Figure $[5,6]$

These results show that stereoselectivities with $\mathrm{Pr}$ values are mostly syndiotatic structure with high Pm value. ${ }^{15}$

\section{CONCLUSIONS}

Binuclear and trinuclear $\beta$ - diketiminate Zinc complexes were reported and act as single, living initiators for the polymerization of rac-lactides to form heterotactic PLA with new architectural properties. The ligand framework is flexible with limited role to provide steric bulk for heterotactic chain -end control.Micro structural analyses of the polymer exert a significant influence to control the stereochemistry of monomer with the tacticity with growing polymer chains and with good PDIs thereby reducing the rate of degradation. Kinetic analysis further supports that the polymerization follows the first order behavior in monomer. Much work needs to be done to fully understand the factors responsible for molecular design of single-site catalyst for steroselective ROP of lactides based on fine tuning the steric and electronic factor of ligand framework to enhance polymerization activity restricting the transesterification reactions.

\section{REFERENCES}

1. R. E. Drumright, P. R. Gruber, D. E. Henton, Adv.Mater., 12, 1841-1846, (2000).

2. T. D. Burchell, Ed. Carbon materials for advanced technologies, Pergamon: Amsterdam, Oxford, 95-118,(1999).

3. A. Kowalski, A. Duda, S. Penczek, Macromol.Rapid communc.,Rapid Commun., 19, 567-572,( 1998).

4. T. M. Ovitt, G. W. Coates, J. Am. Chem. Soc., 124, 1316-1326, (2002). (b) S. Doherty, R. J. Errington, N. Housley, W. Clegg,Organometallics, 23, 2382-2388,(2004).

5. M. H. Chisholm, C. C. Lin, J. C. Galluccia, B. T. Ko,Dalton Trans., 406412,(2003).

6. Y. Sarazin, M. Schormann, M. Bochmann, Organometallics, 23,32963302,(2004).

7. F.Drounin, P.O. Oguadinma,T.J.J. Whitehorne,R.E.P.Homme,F.Schaper, Organometallic, 29,2139-2147,(2010).

8. J.D.Farwell,P.B.Hitchcock, M.F. Lappert, G.A.Luinstra, A.V. Protchenko,X.H.Wei, Jl.Organometallic.Chem., 10,1861-1869, (2008).

9. C.A.Wheaton, P.G.Hayes, Dal.Trans., 39,3861-3869, (2010).

10. M. P. Coles, P. B. Hitchcock, Eur. J. Inorg. Chem., 2662-2672,(2004).

11. B. J. Ireland, C. A. Wheaton and P. G. Hayes, Organometallics, 29, 1079$1084,(2010)$

12. J. Chai, H. Zhu, H. W. Roesky, H. G. Schmidt, M. Noltemeyer, Organometallics, 23, 3284-3289,(2004).

13. E. Shaviv, M. Botoshansky, M. S. Eisen,J. of Organometallic Chem.,683, 165-180,(2003).

14. A. P. Dove, V. C. Gibson, E. L. Marshall, A. J. P. White, A. J. P.; D. Williams, Dalton Trans, 570-578,(2002).

15. D. R. Moore, M. Cheng, E. B. Lobkovsky, G. W. Coates ,J. Am. Chem. Soc.,125, 11911-11924,(2003).

16. G. W. Coates, Chemical Rev., 100, 1223-1252,(2002). 